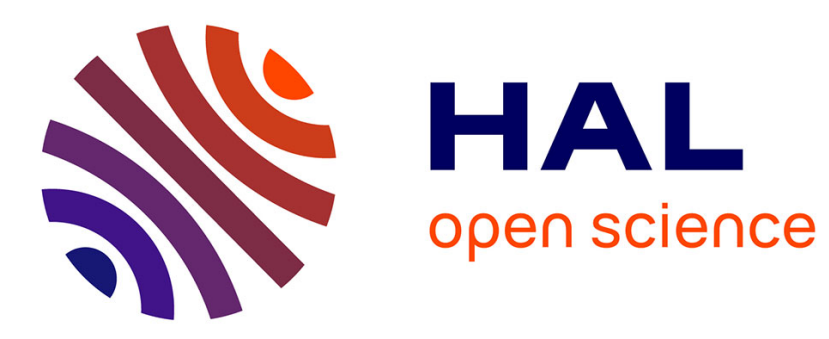

\title{
Determination and characterization of deep levels in $\mathrm{p}-\mathrm{CdTe}(\mathrm{Cl})$
}

\author{
P. Höschl, P. Polivka, V. Prosser, M. Vanecek, M. Skrivankova
}

\section{To cite this version:}

P. Höschl, P. Polivka, V. Prosser, M. Vanecek, M. Skrivankova. Determination and characterization of deep levels in p-CdTe $(\mathrm{Cl})$. Revue de Physique Appliquée, 1977, 12 (2), pp.229-233. 10.1051/rphysap:01977001202022900 . jpa-00244148

\section{HAL Id: jpa-00244148 https://hal.science/jpa-00244148}

Submitted on 1 Jan 1977

HAL is a multi-disciplinary open access archive for the deposit and dissemination of scientific research documents, whether they are published or not. The documents may come from teaching and research institutions in France or abroad, or from public or private research centers.
L'archive ouverte pluridisciplinaire HAL, est destinée au dépôt et à la diffusion de documents scientifiques de niveau recherche, publiés ou non, émanant des établissements d'enseignement et de recherche français ou étrangers, des laboratoires publics ou privés. 


\title{
DETERMINATION AND CHARACTERIZATION OF DEEP LEVELS IN p-CdTe(Cl) (*)
}

\author{
P. HÖSCHL, P. POLÍVKA, V. PROSSER, M. VANĚČEK \\ Institute of Physics of the Charles University Ke Karlovu 5, 12116 Prague 2, Czechoslovakia
}

\author{
M. SKŘIVÁNKOVÁ \\ Institute of Nuclear Research 25068 Řež, Czechoslovakia
}

\begin{abstract}
Résumé. - On a préparé des monocristaux de tellurure de cadmium par la méthode de Bridgman en vue d'étudier leurs propriétés physiques et de réaliser des détecteurs de rayonnements nucléaires. Les cristaux sont compensés au chlore en cours de tirage par addition de $\mathrm{CdCl}_{2}$ à des concentrations de 100-5 000 ppm.

Afin de déterminer la distribution des niveaux donneurs et accepteurs présents dans ces matériaux, nous avons entrepris des mesures d'effet Hall, de photoconductivité, de courants thermostimulés, de mobilité, de courants de charge d'espace. Les résultats obtenus sont ensuite confrontés à un modèle considérant un effet de pairage donneur-accepteur convenablement placé dans le réseau.

En détection nucléaire, nous obtenons typiquement les résolutions en énergie suivantes : des largeurs à mi-hauteur de raies de $7 \mathrm{keV}$ pour des photons de $122 \mathrm{keV}\left({ }^{57} \mathrm{Co}\right)$ et de $5 \mathrm{keV}$ pour des photons de $59 \mathrm{keV}\left({ }^{241} \mathrm{Am}\right)$.
\end{abstract}

\begin{abstract}
CdTe single crystals grown from Te solvent have been used for both evaluation of physical parameters and preparation of nuclear radiation detectors. Ingots were doped with $\mathrm{Cl}\left(\mathrm{CdCl}_{2}\right)$ in the range of $100-5000 \mathrm{ppm}$.

For the experimental determination of the distribution of the donor and acceptor levels in $\mathrm{CdTe}(\mathrm{Cl})$ the Hall effect, photoconductivity, drift mobilities, thermo-stimulated currents (TSC) and space charge limited currents (SCLC) were employed. The results are compared with a model based on acceptor-donor pairs separated by distinct distance within the crystal lattice.

For a typical detector produced from $\mathrm{p}-\mathrm{CdTe}(\mathrm{Cl})$ the total resolution was approximately $7 \mathrm{keV}$

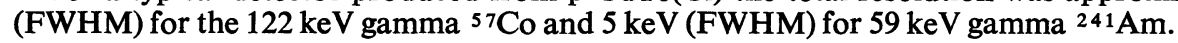

1. Introduction. - Nuclear radiation spectrometers made from chlorine doped CdTe single crystals grown from tellurium solvent have a good resolution for gamma-rays, when operating at room temperature. Recent work on $\mathrm{CdTe}(\mathrm{Cl})$ detectors has indicated the importance that charge transport and trapping effects have in limiting detector performance.

In an effort to understand the trapping in $\mathrm{CdTe}(\mathrm{Cl})$ detectors the distribution of energy levels in band gap was studied in some detail.

The investigation of the energy levels system of charged centres in CdTe, as well as in other II-VI compounds, presents a complicated problem not yet well understood.

In section 2 the method of preparation is described, including the growing techniques. In section 3 is presented a model of self-compensation and distribution of energy levels in the band gap of CdTe. The experimental results, determined from the Hall effect, photoconductivity, drift mobilities, thermostimulated currents and space charge limited currents, are summarized in section 4 , including a comparison

(*) This work was sponsored by Czechoslovak Atomic Energy Commission. between theory and experimental data. The parameters of $\mathrm{CdTe}(\mathrm{Cl})$ gamma-ray detectors are presented in section 5 .

2. Crystal growth. - The vertical Bridgman method was used to grow CdTe single crystals by directional cooling of a $\mathrm{Te}$ - rich solution of the composition 30 at $\% \mathrm{Cd}$ and 70 at $\% \mathrm{Te}$.

A charge of $\mathrm{Cd}: 6 \mathrm{~N}$ and Te : $6 \mathrm{~N}$ redestilled in a stream of pure hydrogen put in a quartz tube, coated with a layer of pyrolytic graphite which was evacuated $\left(10^{-5}\right.$ torr). Synthesis of CdTe and homogenization of the charge was realized by heating the tube in a direct flame. After synthesis the tube was inserted into furnace and was pulled through the temperature gradient (Fig. 1a). Dependence of solid CdTe fraction during pulling on the temperature of growing interface is given in figure $1 b$.

Ingots were prepared, both undoped and doped with chlorine, which was added, in the form of anhydrous salt $\mathrm{CdCl}_{2}$ to the charge. The concentration of chlorine in the total charge was varied from 100 to 5000 ppm.

In agreement with results obtained in Tyco Laboratories [1], CdTe crystals grown from tellurium 

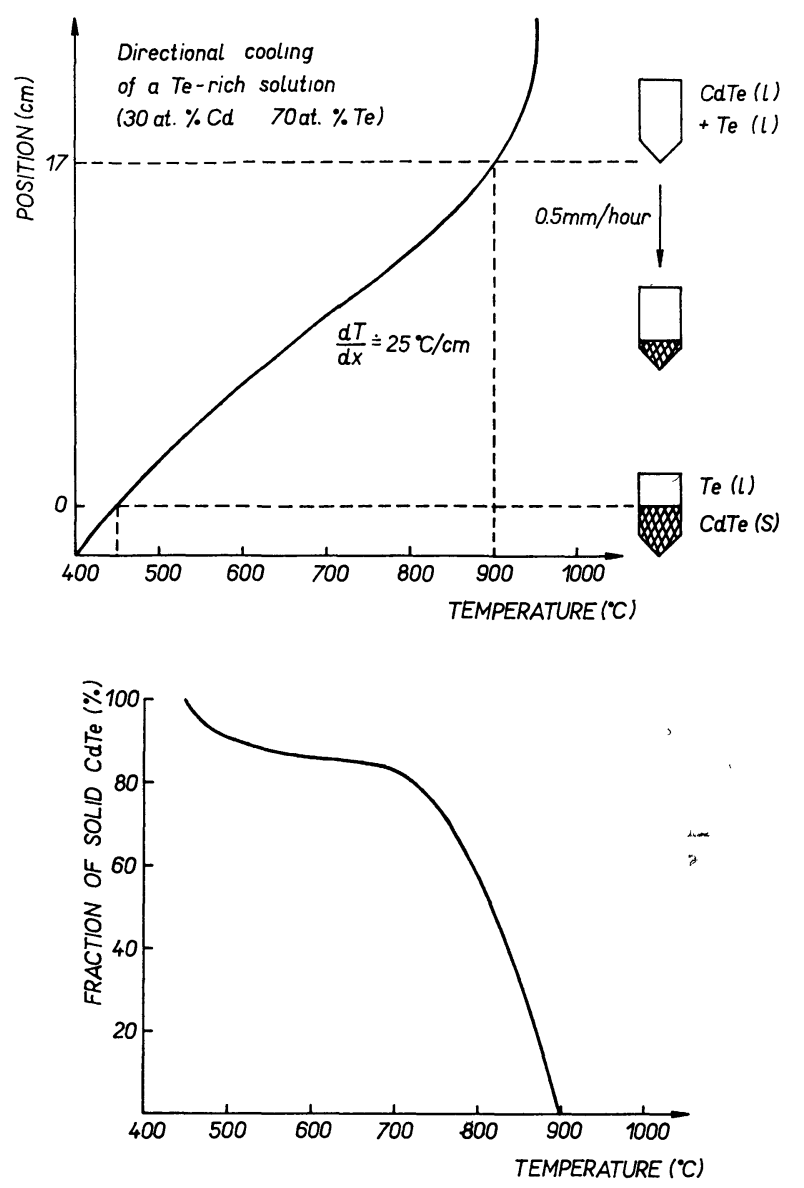

Fig. 1. - a) Temperature distribution and positions of ampoule in the furnace during pulling the CdTe single crystals from tellurium melt. $b$ ) Fraction of solid CdTe, calculated from phase diagram of the system Cd-Te [12].

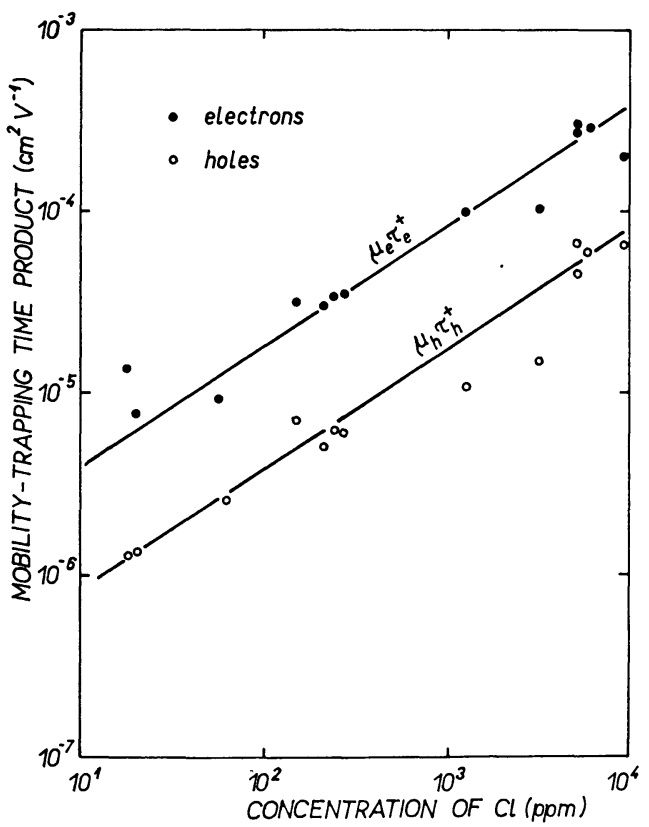

Fig. 2. - Mobility-trapping time products $\mu \tau^{+}$for both electrons and holes as function of total concentration of chlorine in the charge. solution and doped with chlorine appear to be the most promising for the preparation of gamma-ray detectors. For that reason we have carried out measurements of mobility-trapping time products $\mu \tau^{+}$for both electrons and holes as a function of the total concentration of chlorine in the charge (Fig. 2). We have used a method in which $\alpha$-particles $\left({ }^{241} \mathrm{Am}\right)$ generate carriers close to one of the contacts, and charge collection efficiency is measured for electrons or holes (Hecht relation).

From figure 2 it can be seen that in proceeding from low to high concentration of chlorine the mobility-trapping time product increases jointly for electrons and holes. The optimum chlorine concentration for radiation detection is around $5000 \mathrm{ppm}$ in the charge.

3. Model and theory. - In CdTe crystals, both foreign atoms and native point defects of Frenkeltype $\left(V_{\mathrm{Cd}}, \mathrm{Cd}_{\mathrm{i}}\right)$ and Schottky-type $\left(V_{\mathrm{Cd}}, V_{\mathrm{Te}}\right)$, determine the electrical properties of crystals. The concentrations of the dopant atoms and defects are not independent on each other. (Kröger's notation [2] for defects will be used throughout this section.) The introduction of electrically active impurities into a host crystal induces the formation of electrically active defects and neutral complexes, which tend to compensate the material. Therefore the process of self-compensation is usually used for the preparation of semi-insulating CdTe.

For $\mathrm{CdTe}(\mathrm{Cl})$, where $\mathrm{Cl}_{\mathrm{Te}}$ acts as shallow donor $\left(\mathrm{Cl}_{\mathrm{Te}}\right)$ there are three possibilities of self-compensation.

(a) The first mechanism is compensation by cadmium vacancies singly or doubly ionized $V_{C_{d}}^{\prime}, V_{C_{d}}^{\prime \prime}$ (acceptors).

(b) The second is compensation by complexes $\left(V_{\mathrm{Cd}} \mathrm{Cl}_{\mathrm{Te}}\right)^{\prime}$ separated by a distinct distance $r$.

(c) Finally a neutral complex consisting of one $V_{\mathrm{Cd}}^{\prime \prime}$ and two $\mathrm{Cl}_{\mathrm{Te}}^{\circ}$ is considered $\left(V_{\mathrm{Cd}} 2 \mathrm{Cl}_{\mathrm{Te}}\right)^{x}[3]$.

In all cases during compensation the difference $\left|N_{\mathrm{A}}-N_{\mathrm{D}}\right|$ decreases; only in the last case individual compoments $N_{\mathrm{A}}, N_{\mathrm{D}}$ decrease too.

Donor-acceptor pairs $\left(V_{\mathrm{Cd}} \mathrm{Cl}_{\mathrm{Te}}\right)$ and associated electronic states play an important role in the investigation of deep acceptor levels in $\mathrm{CdTe}(\mathrm{Cl})$. In this case association takes place acording to the quasichemical reactions :

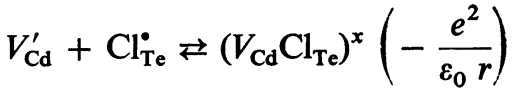

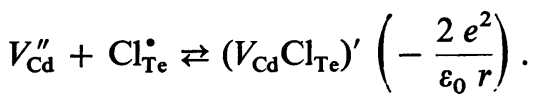

Acceptors $V_{\mathrm{Cd}}^{\prime}$ and $\left(V_{\mathrm{Cd}} \mathrm{Cl}_{\mathrm{Te}}\right)^{x}$ can be ionized; thus :

$$
\begin{aligned}
\left(V_{\mathrm{Cd}} \mathrm{Cl}_{\mathrm{Te}}\right)^{\prime} & \rightleftarrows\left(V_{\mathrm{Cd}} \mathrm{Cl}_{\mathrm{Te}}\right)^{x}+e^{\prime}\left(E_{\mathrm{gap}}-\Delta E(r)\right) \\
V_{\mathrm{Cd}}^{\prime \prime} & \rightleftarrows V_{\mathrm{Cd}}^{\prime}+e^{\prime}\left(E_{\mathrm{gap}}-\Delta E^{\prime \prime}\right)
\end{aligned}
$$


where $\Delta E(r), \Delta E^{\prime \prime}$ are the ionization energies of complex $\left(V_{\mathrm{Cd}} \mathrm{Cl}_{\mathrm{Te}}\right)^{\prime}$ and doubly ionized cadmium vacancy, $\varepsilon_{0}$ is the low frequency dielectric constant and $e$ is the electronic charge. $W_{\mathrm{e}}$ can easily see that

$$
\Delta E(r)=\Delta E^{\prime \prime}-\frac{e^{2}}{\varepsilon_{0} r} \text {. }
$$

Corrections to simple coulombic considerations which are important for small $r$ will be neglected here.

For acceptors on cation sites $-V_{\mathrm{Cd}}$ and donors on anion sites $-\mathrm{Cl}_{\mathrm{Te}}$, the possible distance between acceptors and donors in the zinc blende structure are given by :

$$
r_{j}=a\left(\frac{1}{2} j-\frac{5}{16}\right)^{1 / 2} \quad j=1,2, \ldots, k
$$

where $a$ is a lattice constant. Discrete values of $r_{j}$ range up to a maximum value $r_{\max }$, equal to $\frac{1}{2} C^{-1 / 3}$ ( $C$... donor and acceptor concentration). Thus, for activation energies of the acceptors $\left(V_{\mathrm{Cd}} \mathrm{Cl}_{\mathrm{Te}}\right)_{j}$ we obtain :

$$
\Delta E^{(j)}=\Delta E^{\prime \prime}-\frac{e^{2}}{\varepsilon_{0} r_{j}}
$$

Prener [4] adapted previous considerations of ion pairing in solution to the case of discrete sites in a three-dimensional lattice. For a pair concentration, separated by the distance $r_{j}$, be found :

$$
N_{j} \approx A C Z_{j} \exp \left(\frac{e^{2}}{\varepsilon_{0} r_{j} k_{0} T}\right) \exp \left(-C \sum_{l=1}^{j} Z_{l}\right)
$$

where $A$ is a normalization constant

$$
\left(\sum_{j=1}^{k} N_{j}=1\right),
$$

$k_{0}$ is the Boltzman constant, $T$ is temperature and $Z_{j}$ is the number of sites available to a positively charged defect $-\mathrm{Cl}_{\mathrm{Te}}$ at a distance $r_{j}$, from a negatively charged defect $-V_{\mathrm{Cd}}^{\prime}$. From eq. (8) is possible to see, that with increasing $j$, the concentration of pairs decreases.

Hall effect measurements in undoped CdTe crystals demonstrate that the concentration of free holes is governed by a level lying $\approx 0.15 \mathrm{eV}$ above the valence band [5]. The hydrogenic value for the acceptor - binding energy can be written as

$$
\Delta E=13.6\left(m_{\mathrm{hh}}^{*} / m_{0}\right) / \varepsilon_{0}^{2} .
$$

With an effective mass of heavy holes

$$
m_{\mathrm{hh}}^{*} / m_{0}=0.89[6]
$$

we then obtain $\Delta E \approx 0.13 \mathrm{eV}$. For this reason we assume that the activation energy for singly ionized $\mathrm{Cd}$ vacancy is $\approx 0.15 \mathrm{eV}$.

From the temperature dependence of carrier concentration in p-type samples we identified an acceptor level $\approx 0.85 \mathrm{eV}$ above the valence band [5]. We

\begin{tabular}{|c|c|c|c|c|c|c|c|c|c|}
\hline & & & Mod & & & Experin & ent $-E$ & $\mathrm{D}, E_{\mathrm{A}}(\mathrm{eV})$ & \\
\hline & & $\underline{j}$ & $\begin{array}{c}r_{j} 10^{8} \\
(\mathrm{~cm}) \\
-\end{array}$ & $\begin{array}{c}E_{\mathrm{D}}, E_{\mathrm{A}} \\
(\mathrm{eV})\end{array}$ & HE & TFT & $\underline{\mathrm{PC}}$ & $\underline{\text { TSC }}$ & SCLC \\
\hline donors & $\mathrm{Cl}_{\mathrm{Te}}$ & & & & & 0.025 & 0.02 & & \\
\hline & $?$ & & & & & 0.050 & 0.05 & & \\
\hline & $V_{\text {Cd }}^{\prime}$ & & & 0.15 & $0.15\left(^{*}\right)$ & 0.15 & 0.16 & & \\
\hline & $\left(V_{\mathrm{Cd}} \mathrm{Cl}_{\mathrm{Te}}\right)_{1}^{\prime}$ & 1 & 2.81 & 0.32 & & $\approx 0.30$ & $\begin{array}{l}0.32 \\
0.36\end{array}$ & $\begin{array}{l}0.30 ; 0.34 \\
0.37 ; 0.40\end{array}$ & \\
\hline & $\left(V_{\mathrm{Cd}} \mathrm{Cl}_{\mathrm{Te}}\right)_{2}^{\prime}$ & 2 & 5.37 & 0.57 & 0.57 & & & 0.5 & $\approx 0.45 ?$ \\
\hline acceptors & $\left(V_{\mathrm{Cd}} \mathrm{Cl}_{\mathrm{Te}}\right)_{3}^{\prime}$ & 3 & 7.06 & 0.64 & $0.65\left({ }^{* *}\right)$ & & & & 0.65 \\
\hline & $\left(V_{\mathrm{Cd}} \mathrm{Cl}_{\mathrm{Te}}\right)_{4}^{\prime}$ & 4 & 8.42 & 0.67 & & & $\approx 0.7$ & & \\
\hline & $\left(V_{\mathrm{Cd}} \mathrm{Cl}_{\mathrm{Te}}\right)_{5}^{\prime}$ & 5 & 9.57 & 0.69 & & & & & \\
\hline & $V_{\mathrm{Cd}}^{\prime \prime}$ & & & 0.85 & $0.85\left(^{* *}\right)$ & & & & \\
\hline$?$ & $?$ & & & & & & 0.12 & & \\
\hline
\end{tabular}
assume, that this is the second ionization level of Cd vacancy.

$$
\begin{gathered}
\text { Values } r_{j}, \Delta E^{(j)} \text { obtained by eq. (6), (7) with } \\
\varepsilon_{0}=9.65, a=6.48 \times 10^{-8} \mathrm{~cm}
\end{gathered}
$$

and $\Delta E^{\prime \prime}=0.85 \mathrm{eV}$ are summarized in the table $\mathrm{I}$.

\section{TABLE I}

Activation energies of levels in semi-insulating $\mathrm{CdTe}(\mathrm{Cl})$

(*) Undoped crystal CdTe.

$(* *)$ Different crystals CdTe(Cl). 
4. Experimental results. - For the detailed study of distribution of energy levels in the band gap, a CdTe crystal doped with $\mathrm{Cl}$ in amount $\approx 5000 \mathrm{ppm}$ was selected, characterized at room temperature by the following parameters : p-type,

$$
\begin{gathered}
\sigma=6.4 \times 10^{-9} \Omega^{-1} \mathrm{~cm}^{-1}, \mu_{\mathrm{H}}=35 \mathrm{~cm}^{2} / \mathrm{V} . \mathrm{s}, \\
p=1.14 \times 10^{9} \mathrm{~cm}^{-3} \\
\mu_{\mathrm{e}} \tau_{\mathrm{e}}^{+}=2 \times 10^{-4} \mathrm{~cm}^{2} / \mathrm{V}
\end{gathered}
$$

and

$$
\mu_{\mathrm{h}} \tau_{\mathrm{h}}^{+}=7 \times 10^{-5} \mathrm{~cm}^{2} / \mathrm{V}
$$

Materials Evaluation.

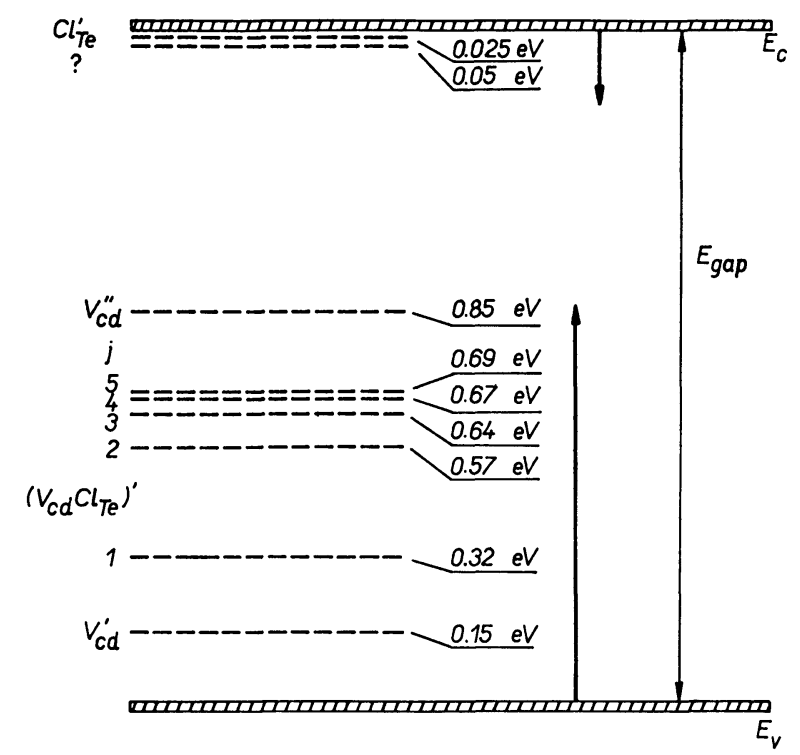

FIG. 3. - Energy levels in the forbidden gap of CdTe (calculated values).

4.1 Hall EfFect (HE). - An activation energy of $\Delta E=0.57 \mathrm{eV}$ denoting an acceptor level was determined on the basis of the measurements of temperature dependence of the Hall constant $\left(r_{\mathrm{H}}=1\right)$. Measurements were performed in a relatively narrowtemperature range since they could not be carried out at low temperatures for which the resistance of samples exceed $10^{12} \Omega$. In undoped samples an activation energy for an acceptor level $\Delta E \approx 0.15 \mathrm{eV}$ was determined.

4.2 Time-OF-Flight TEChNiQue (TFT). - Drift velocity measurements for both electrons and holes have been performed as a function of electrical field and temperature, with charge carriers generated by a pulsed electron beam. From reduced mobility we have obtained the following levels : $0.025 \mathrm{eV}$ below conduction band and $0.15 \mathrm{eV}$ above valence band. The activation energies of traps: $E_{\mathrm{C}}-0.05 \mathrm{eV}$, $E_{\mathrm{V}}+0.15 \mathrm{eV}$ and $\mathrm{E}_{\mathrm{v}}+0.3 \mathrm{eV}$ were also obtained by measuring the $0-85 \%$ voltage pulse rise-time of the waveforms (two components) and changing the temperature. A more detailed discussion is found in [7]. All these measurements were performed in the laboratory of prof. G. Ottaviani at Modena University during the fellowship stay of one of the authors.

4.3 Photoconductivity (PC). - Photoconductivity spectra were recorded in the $0.1 \mathrm{eV}-1.6 \mathrm{eV}$ region at the temperatures $15 \mathrm{~K}$ and $80 \mathrm{~K}$. Impurity photoconductivity was measured with and without additional illumination. The illumination with energy $h v=E_{\text {gap }}$ was employed in order to shift the positions of quasiFermi levels within the forbidden gap of CdTe. The amplitude and phase shift of photocurrent were investigated. The energy of the impurity levels was determined according to Bube [8] and Ryvkin [9]. Obtained impurity levels are following :

$$
\begin{gathered}
E_{\mathrm{C}}-0.025 \mathrm{eV} ; E_{\mathrm{C}}-0.055 \mathrm{eV} ; E_{\mathrm{V}}+0.7 \mathrm{eV} ; \\
E_{\mathrm{V}}+0.36 \mathrm{eV} ; E_{\mathrm{V}}+0.32 \mathrm{eV} ; \\
E_{\mathrm{V}}+0.16 \mathrm{eV} \text { and } E_{\mathrm{C}}-0.12 \mathrm{eV} \text { or } E_{\mathrm{V}}+0.12 \mathrm{eV}
\end{gathered}
$$

4.4 Space CHARge Limited CURRENTS (SCLC). The D. C. measurements of currents have been performed on samples $\mathrm{CdTe}(\mathrm{Cl})$ with platinum contacts as a function of the applied voltage for different temperatures in the range $100 \mathrm{~K}-300 \mathrm{~K}$. From the temperature dependence of the quadratic partions of the voltage-current characteristics a discrete level at $E_{\mathrm{V}}+0.65 \mathrm{eV}$ with a fair accuracy could be identified. Another one at approx. $E_{\mathrm{V}}+0.45 \mathrm{eV}$ was found with lower accuracy [10].

4.5 Thermo STIMUlated CURRENTS (TSC). TSC measurements were performed with a standard technique in the range between $100 \mathrm{~K}$ and $300 \mathrm{~K}$ after optical, electrical or combined excitations, both at low temperatures or during the cooling process. Where possible, the "cleaning" of the TSC-curves by interrupted heating was applied to separate the individual maxima. Five levels most probably associated to hole traps were identified by means of the initial rise method

$$
\left(E_{\mathrm{t}}=k \frac{\mathrm{d}(\log I)}{\mathrm{d}(l / T)}\right)
$$

and from the temperature at maximum current

$$
\text { (Bube's method, } E_{\mathrm{t}}=k T_{\max } \log \frac{N_{\mathrm{v}}}{p} \text { ) }
$$

respectively.

A fairly good agreement $(\sim 1.5 \%)$ between both values indicates a strong recapture of holes on these levels.

The averaged trap energies obtained were the following; $0.30 \mathrm{eV} ; 0.34 \mathrm{eV} ; 0.37 \mathrm{eV} ; 0.40 \mathrm{eV}$; $0.5 \mathrm{eV}$. There is an indication of a level at $E_{\mathrm{t}}>0.5 \mathrm{eV}$. The details will be published elsewhere [11].

All obtained results are summarized in table $I$. 
5. Radiation detector characteristics. - Detectors of gamma radiation were prepared from the same $\mathrm{CdTe}(\mathrm{Cl})$ single crystal used for material evaluation.

Detectors were fabricated in the forms of plates $5 \times 5 \times 1 \mathrm{~mm}^{3}$, whose faces were lapped and mechanically polished to optical quality. The electrodes were deposited by chemical precipitation of gold $\left(\mathrm{AuCl}_{3}\right)$.

The quality of the detectors was tested with ${ }^{57} \mathrm{Co}$ and ${ }^{241} \mathrm{Am}$ sources. In the ${ }^{57} \mathrm{Co}$ spectrum (Fig. 4), low noise is demonstrated by the presence of $14 \mathrm{keV}$

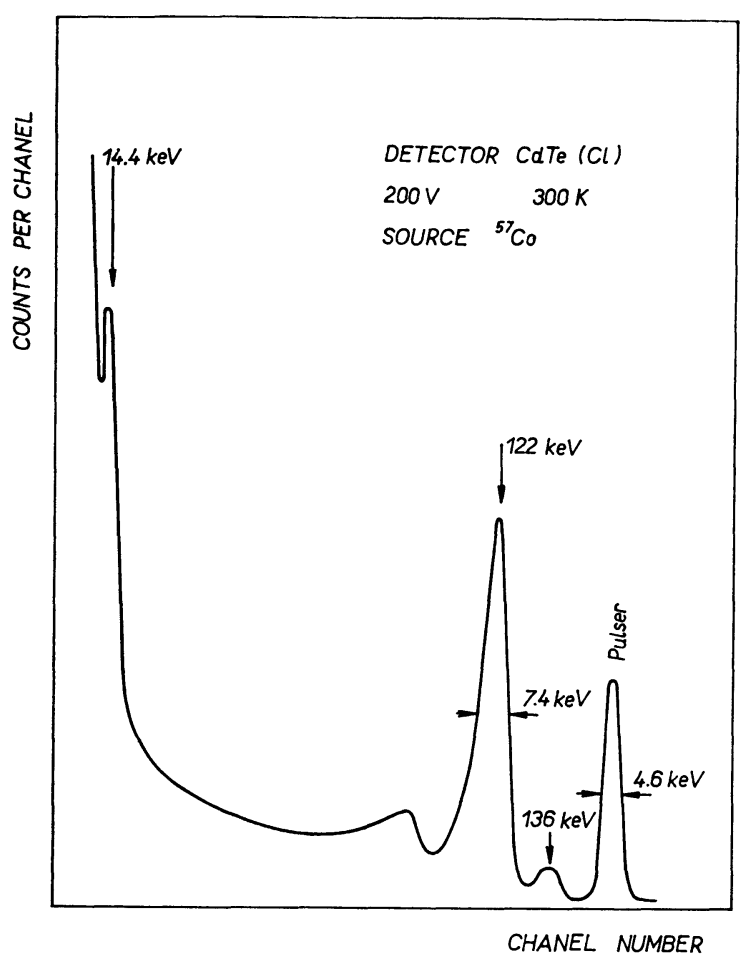

FIG. 4. - ${ }^{57} \mathrm{Co}$ gamma-ray spectrum at room temperature. peak and good resolution $\approx 7 \mathrm{keV}$ (FWHM) is evident from the separation of $122 \mathrm{keV}$ and $136 \mathrm{keV}$ peaks. In ${ }^{241} \mathrm{Am}$ spectrum (Fig. 5) both peaks $L_{a}$ $14 \mathrm{keV}$ and $L_{\beta} 18 \mathrm{keV}$ are well resolved. The $\mathrm{CdTe}(\mathrm{Cl})$ detectors are stable with time; they exhibit no polarization.

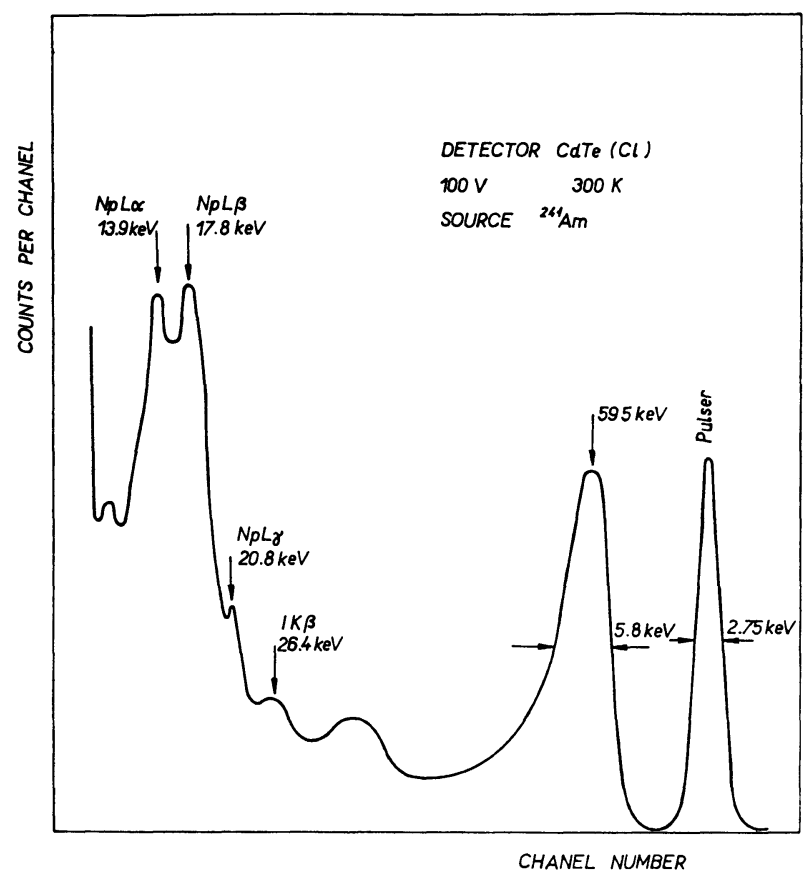

FIG. 5. - ${ }^{241} \mathrm{Am}$ gamma-ray spectrum at room temperature.

Acknowledgements. - We would like to express our thanks to V. Kubla for his experimental assistance in growing the crystals and M. Vidra for his help in radiation detector measurements.

\section{References}

[1] Serreze, H. B., Eutine, G., Bell, R. O., Wald, F. V., IEEE Tran. Nucl. Sci. 21 (1974) 404.

[2] KRöGER, F. A., The Chemistry of Imperfect Crystals (NorthHolland, Amsterdam) 1964.

[3] Canali, C., Ottaviani, G., Bell, R. O., Wald, F. V., J. Phys. Chem. Sol. 35 (1974) 1405.

[4] Prener, J. S., J. Chem. Phys. 25 (1964) 1294.

[5] Höschl, P., Polívka, P., Prosser, V., Sakalas, A., Czech. J. Phys. B 25 (1975) 585.

[6] VANĚČEK, M., KLIER, E., Phys. Stat. Sol. (a) 30 (1975) 441.
[7] Höschl, P., Polívka, P., NAva, F., Minder, R., Czech. J. Phys. B 26 (1976) 812

[8] BuBe, R. H., Photoconductivity of Solids (J. Wiley, Sons, N. Y.) 1960.

[9] RyvkIN, S. M., Photoelectric effects in semiconductors. (Consultants Bureau, N. Y.) 1974.

[10] Zoul, A., KuIER, E., to be published in Czech. J. Phys.

[11] Vierebl, L., KLIER, E., to be published.

[12] Hansen, M., Constitution of Binary Alloys (McGraw Hill, N. Y.) 1958. 